\title{
Enlargement of Amanatun, South Central Timor Regency
} Jarot Soleman Ndaong ${ }^{1}$, Surjono ${ }^{2}$, N Nyoman Suluh Wijaya ${ }^{3}$

\author{
${ }^{1}$ Magister Program of Regional and City Planning Department, Engineering Faculty, Brawijaya University \\ ${ }^{2,3}$ Regional and City Planning Department, Engineering Faculty, Brawijaya University
}

\begin{abstract}
South Central Timor Regency is one of the Regency within the Province of East Nusa Tenggara. It lies on 3955,36 km2 with 32 Sub-Districts and population of 459.310 people which made it as Regency with most Kecamatan (SubDistrict) and most populated area in Province of East Nusa Tenggara. Thus, due it its large size, less optimum service of regional government regarding might occur. One solution offered for this issue was regional enlargement, which become the proposed enlargement of Amanatun. Amanatun was taken from the name of a kingdom during West Indies governance, which was includes in Afdeeling (Regency) South Central Timor. This proposition of Amanatun enlargement was having its own background that became the trigger and objectives of the people who desire this enlargement. Objectives of this study was to discover the triggers and objectives expected from Amanatun enlargement and whether there was relationship between the trigger and objectives of Amanatun enlargement also what is the form of this enlargement according to the prevails laws and regulations. Analysis process was using Partial Least Square (PLS) and appropriateness level for enlargement was based on government regulation guidelines.
\end{abstract}

Keywords - regional enlargement, trigger, objectives, relationship between effect of trigger toward objectives of enlargement, PLS, appropriateness level of enlargement based on laws and regulations.

\section{INTRODUCTION}

Regional development in Indonesia particularly regional enlargement started to flourish after 1998. Since there was the change from centralized to decentralization (autonomy), a region could be developed and become independent. This was supported by policy regulating about regional government such as UU 22 of 1999 with PP 129 of 2000 replaced with UU 32 of 2004 with PP 78 of 2007 and UU 23 of 2014.

There were various aspect which affect regional enlargement in Indonesia, such as religious differences, ethnic/cultural differences, development imbalances, vastness of regional area, political factor either regarding power or political representation within regional government also the existence of regional fiscal fund. Regional enlargement was aimed to improve community's welfare such as giving optimum service for citizen, development of local potential so that it would increase economic growth, opened more employment sector, lessened disparity between central and regional, regional potential can be managed in good and faster manner, improved safety and order, also better relationship between central and regional government.

Regarding issue and plans concerning regional enlargement developed in TTS Regency since 2013 until date, author would like to conduct review about the proposed enlargement, started with answering questions such as what triggers this enlargement and what are the objectives to achieved also what is the form of enlargement based on the prevails laws and regulations.

Study site was located in South Central Timor Regency. Its population in 2016 was 443.111 people, and by far is the most populated area compared to other Regency in the Province of NTT. From number of Sub-Districts, TTS Regency has 32 subdistricts and thus known as Regency with the most sub-districts in the Province of NTT. This might the reason behind less optimum service for its citizen. Enlargement plan of Amanatun consist of 8 sub-districts (Amanatun Utara, Amanatun Selatan, Boking, Toianas, Nunkolo, Kokbaun, Santian and Noebana). 


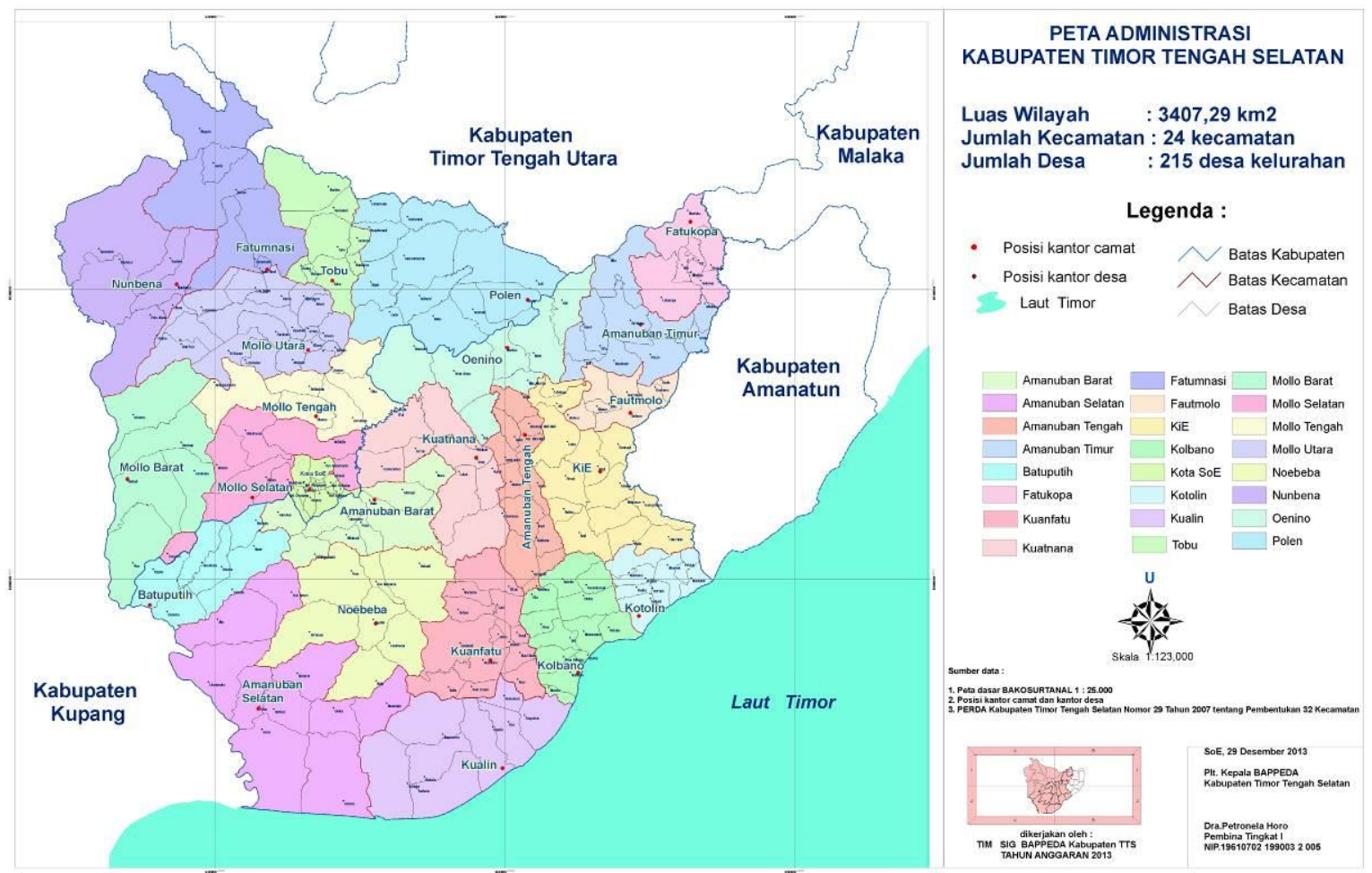

Figure 1. SOUTH CENTRAL TIMOR REgenCy (AFTER AMANATUN ENLARGEMENT)

\section{MATERIALS AND METHODS}

This study is a quantitative descriptive study with Partial Least Square (PLS) approach, with purposive sampling and Likert scale as its sample collection technique. Gravimetric and quota method in calculating the appropriateness of Amanatun enlargement was based on Government Regulation (Peraturan Pemerintah) No 78 of 2007. Formulation of study variables was used as the main reference to answer problematic questions and act as basic reference for analysis processing.

TABLE 1

STUDY VARIABLES

\begin{tabular}{|c|c|c|c|}
\hline No & Objectives & Variables & Sub Variables \\
\hline 1. & $\begin{array}{l}\text { Discover the trigger of Amanatun } \\
\text { enlargement }\end{array}$ & Trigger of enlargement & $\begin{array}{l}\text { - Religious differences } \\
\text { - Ethnic/cultural differences } \\
\text { - Economic imbalances } \\
\text { - Vastness of regional area } \\
\text { - Political reason } \\
\text { - Fiscal fund allocation }\end{array}$ \\
\hline 2. & $\begin{array}{l}\text { Discover the objectives of } \\
\text { Amanatun enlargement }\end{array}$ & Objectives of enlargement & $\begin{array}{l}\text { - Improved service for citizen } \\
\text { - Faster growth in democratic life } \\
\text { - Faster regional development } \\
\text { - Labor absorption } \\
\text { - Faster regional potential management } \\
\text { - Improved safety and order } \\
\text { - Improved harmony relationship } \\
\text { between central and regional }\end{array}$ \\
\hline 3. & $\begin{array}{l}\text { Discover the effect of the trigger } \\
\text { toward the objectives of enlargement }\end{array}$ & Trigger and Objectives & Hypothetical test \\
\hline 4. & $\begin{array}{l}\text { Discover the appropriateness of } \\
\text { Amanatun enlargement based on the } \\
\text { existed UUs and PPs. }\end{array}$ & PP 78 of 2007 & $\begin{array}{l}\text { Appropriateness Level of Amanatun } \\
\text { Enlargement }\end{array}$ \\
\hline
\end{tabular}

Source: Referential Compilation 


\subsection{Data Collection Method}

Data collection method used in this study was through primary and secondary survey. Primary survey was done through observation, interview and questionnaire dispersion. Number of respondent in this study were 40 respondents with purposive sampling approach in which respondent was selected under consideration that he or she was informed and involved in the process of Amanatun enlargement. Secondary survey was done by collecting data related with Amanatun enlargement.

\subsection{Data Analysis Technique}

In analyzing the trigger of enlargement, objectives of enlargement and relationship/effect of the trigger toward the objectives of Amanatun enlargement, we use Partial Least Square (PLS) analysis with sample collection technique using purposive sampling, under the consideration that sample determination was taken from:

- Unknown population

- $\quad$ Not all people involved in Amanatun enlargement

- $\quad$ Minimum samples in PLS is 30-100

Number of respondents in this study was 40 respondents, in which they were asked to answer the questions by using Likert scale. Likert scale was used to find social symptom and event occurs among people by measuring perception, attitude and opinion of individuals within community, whereas variables would be made into sub-variables and then used as measurable indicators (Sugiyono, 2012). PLS analysis is part of Structural Equation Modelling (Ghozali, 2014). Several benefits of PLS are:

- Distribution free approach

- $\quad$ PLS objective is to predict or to developed a theory

- $\quad$ Small sample (30-100 samples)

- Indicator was reflective and formative

- It can be used as an alternative for structure equation modelling which has weak theory

- $\quad$ PLS can be used for theoretical testing and also can be used for exploratory or to test relationship which has no theory of it.

- $\quad$ PLS is using SmartPLS and VisualPLS softwares.

\section{Steps in PLS consist of:}

\section{Step 1: Creating a path diagram}

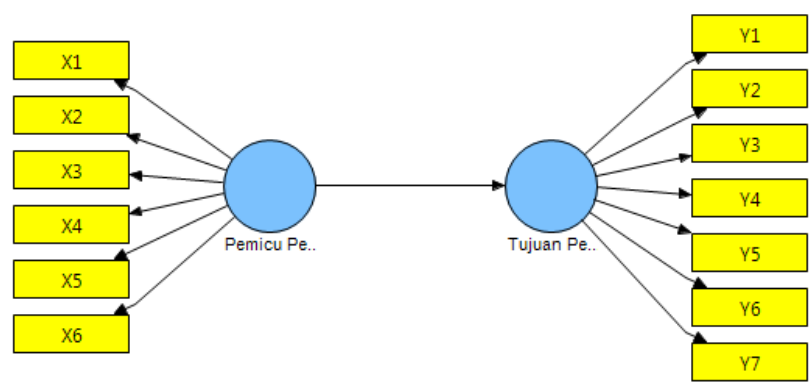

Figure 2: PATH Diagram MOdel OF PLS With SMaRtPLS 3.0 SOFTWARE

\section{Step 2: Conversion of path diagram into structural model}
a. $\quad$ Struktural model (inner model)
b. Measurement model (outer model)

\section{Step 3: Conduct Godness of Fit evaluation}

c. Evaluation of measurement model 


\section{d. Evaluation of structural model}

\section{Step 4: Hypothetical testing (Interpretation)}

Hypothetical testing in PLS was using T-test or t-statistic and $p$-values.

\section{TABLE 2}

VARIABLES IN PLS MODEL

\begin{tabular}{|l|l|l|}
\hline No & Latent Variables & Manifested Variables (Indicator) \\
\hline 1. & Objective of Enlargement (Y) & Y1 = Improved service for citizen \\
& & Y2 = Faster democratic growth for citizen \\
& & Y3 = Faster regional economic development \\
& & Y4 = Labor absorption \\
& & Y5 = Faster management concerning regional's potential \\
& & Y6 = Improved safety and order in regional area \\
& & Y6 = Faster management concerning regional's potential \\
& & Y6 = Improved safety and order in regional area \\
& & Y7 = Improved relationship between central and regional government and \\
& Trigger of Enlargement & vice versa \\
\hline 2. & X1 = Religious differences \\
& & X2 = Ethnic/cultural differences \\
& & X3 = Economic imbalances \\
& & X4 = Vastness area of regional \\
& & X5 = Political reason \\
& & X6 = Fiscal fund allocation \\
\hline
\end{tabular}

Source : Analysis result

For enlargement analysis based on PP 78 of 2007, quota and gravimetric analysis was used to determine the appropriateness of regional enlargement.

\section{RESULT AND DISCUSSION}

\subsection{Partial Least Square (PLS) Analysis}

PLS analysis was using SmartPLS 3.0 software. Steps in this PLS analysis were:

\subsubsection{Constructing path diagram}

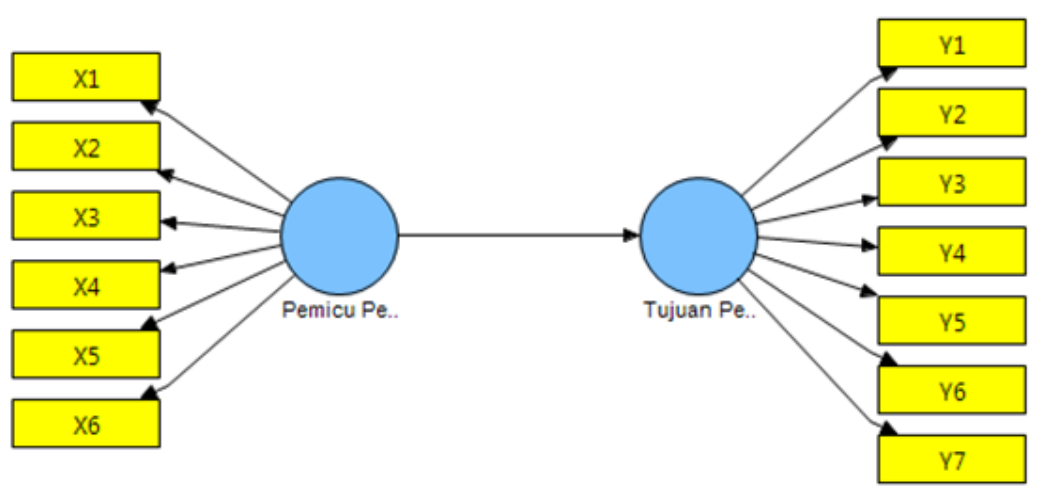

Figure 3. Path diagram of PLS

\subsubsection{Conversion of path diagram into equation system}

a. Structural model (inner model)

$$
Y=\gamma X+\varsigma
$$

b. Measurement model (outer model)

i. Variabel X (reflektive) 


$$
\begin{aligned}
& \mathrm{X} 1=\lambda \mathrm{y} \mathrm{X}+\xi 1 \\
& \mathrm{X} 2=\lambda \mathrm{yX}+\xi 2 \\
& \mathrm{X} 3=\lambda \mathrm{y} \mathrm{X}+\xi 3 \\
& \mathrm{X} 4=\lambda \mathrm{y} \mathrm{X}+\xi 4 \\
& \mathrm{X} 5=\lambda \mathrm{y} \mathrm{X}+\xi 5 \\
& \mathrm{X} 6=\lambda \mathrm{y} \mathrm{X}+\xi 6
\end{aligned}
$$

ii. Variabel $\mathrm{Y}$ (reflektive)

$$
\begin{aligned}
\mathrm{Y} 1 & =\lambda \mathrm{y} \mathrm{Y}+\xi 1 \\
\mathrm{Y} 2 & =\lambda \mathrm{y} \mathrm{Y}+\xi 2 \\
\mathrm{Y} 3 & =\lambda \mathrm{y} \mathrm{Y}+\xi 3 \\
\mathrm{Y} 4 & =\lambda \mathrm{y} \mathrm{Y}+\xi 4 \\
\mathrm{Y} 5 & =\lambda \mathrm{y}+\xi 5 \\
\mathrm{Y} 6 & =\lambda \mathrm{y}+\xi 6 \\
\mathrm{Y} 7 & =\lambda \mathrm{y}+\xi 7
\end{aligned}
$$

\subsubsection{Conduct Goodness of Fit evaluation}

Goodness of Fit evaluation was done to find out model's appropriateness, either for measurement model (outer model) and structural model (inner model).

\section{a. Evaluation of measurement model (outer model)}

For evaluation of measurement model (outer model), we used PLS with validity and reliability test, validity test were convergent validity and discriminant validity. Convergent validity was determined by outer loadings value $>0,5$

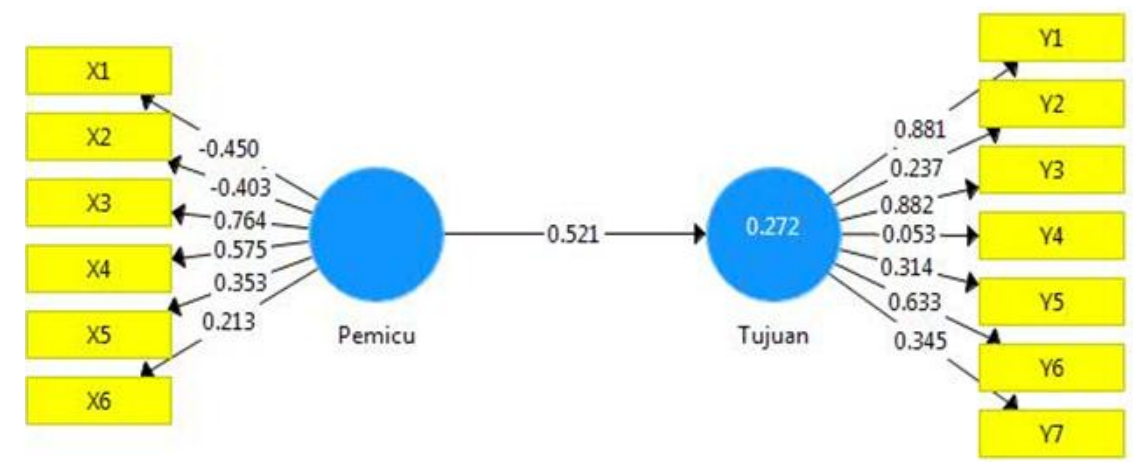

FigURE 4. CALCULATION RESULT FOR PLS ALGORITHM

TABLE 3

LOADINGS VALUE BETWEEN INDICATORS

\begin{tabular}{|c|c|c|c|}
\hline Variables & Nilai Loading & Keterangan \\
\hline \multirow{4}{*}{$\begin{array}{c}\text { X } \\
\text { X }\end{array}$} & -0.450 & Insignificant \\
\cline { 2 - 4 } & $\mathrm{X} 2$ & -0.403 & Insignificant \\
\cline { 2 - 4 } & $\mathrm{X} 3$ & 0.764 & Valid and significant \\
\cline { 2 - 4 } & $\mathrm{X} 4$ & 0.575 & Valid and significant \\
\cline { 2 - 4 } & $\mathrm{X} 5$ & 0.353 & Insignificant \\
\cline { 2 - 4 } & $\mathrm{X} 6$ & 0.213 & Insignificant \\
\hline \multirow{4}{*}{$\begin{array}{c}\text { Trigger of Enlargement) } \\
\text { (Objective of Enlargement) }\end{array}$} & $\mathrm{Y} 1$ & 0.881 & Valid and significant \\
\cline { 2 - 4 } & $\mathrm{Y} 2$ & 0.237 & Insignificant \\
\cline { 2 - 4 } & $\mathrm{Y} 3$ & 0.882 & Valid and significant \\
\cline { 2 - 4 } & $\mathrm{Y} 4$ & 0.053 & Insignificant \\
\cline { 2 - 4 } & $\mathrm{Y} 5$ & 0.314 & Insignificant \\
\cline { 2 - 4 } & $\mathrm{Y} 6$ & 0.633 & Valid and significant \\
\cline { 2 - 4 }
\end{tabular}

Source : SmartPLS processing results

From PLS Algorithm results, indicators X1, X2, X4, X5, X6, Y2, Y4, Y5, Y6 and Y7 were omitted because it has loading value less than 0.5 and insignificant. After omission completed, it was recalculated. 


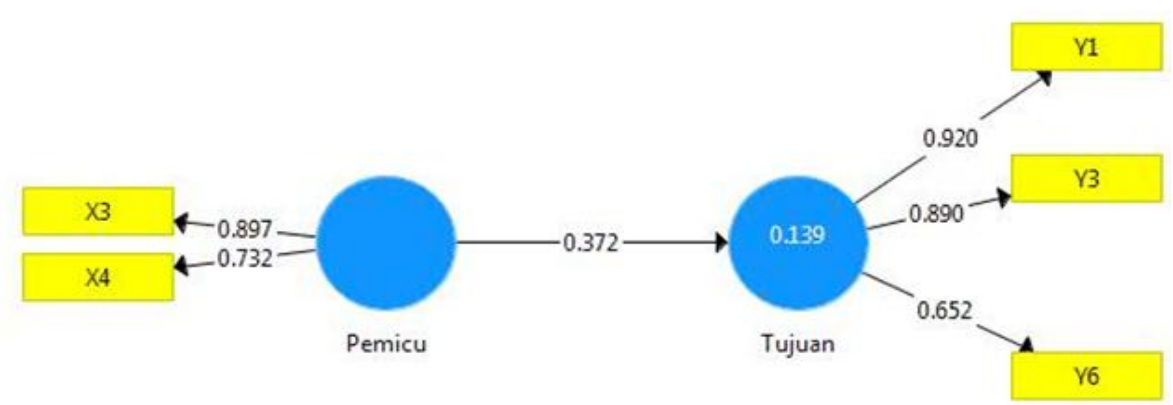

FIGURE 5. RECALCULATION RESULT FOR PLS ALGORITHM

TABLE 4

LOADING VALUES AND VARIANCE INFLATION FACTOR (VIF) BETWEEN INDICATORS

\begin{tabular}{|c|c|c|c|c|}
\hline \multicolumn{2}{|c|}{ Variables } & loadingValue & VIF Value & Information \\
\hline X & $\mathrm{X} 3$ & 0.897 & 1.145 & Valid and significant \\
\cline { 2 - 5 } (Trigger of Enlargemen) & $\mathrm{X} 4$ & 0.732 & 1.145 & Valid and significant \\
\hline \multirow{3}{*}{ Y } & $\mathrm{Y} 1$ & 0.920 & 2.034 & Valid and significant \\
\cline { 2 - 5 } (Tujuan Pemekaran) & $\mathrm{Y} 3$ & 0.890 & 1.995 & Valid and significant \\
\cline { 2 - 5 } & $\mathrm{Y} 6$ & 0.652 & 1.358 & Valid and significant \\
\hline
\end{tabular}

Source : SmartPLS processed results

From the table above it can be seen that loading value of each indicator was above 0.5 and its variance inflation factor (VIF) value was $>0.1$ and $<10$. For discriminant validity, it can be seen by looking at cross loading correlation value of indicator with its construct and its average variance extracted (AVE) of each construct whereas good model would have AVE value of its construct $>0.50$. Cross loading value in this model can be seen from table below.

TABLE 5

\section{CROSS LOADING VALUES}

\begin{tabular}{|c|c|c|}
\hline & X (trigger) & Y (objective) \\
\hline X3 & 0.897 & 0.359 \\
\hline X4 & 0.732 & 0.233 \\
\hline Y1 & 0.386 & 0.920 \\
\hline Y3 & 0.323 & 0.890 \\
\hline
\end{tabular}

Source: SmartPLS processing result

From the table above, it can be seen that cross loading value of trigger variables with its indicators (X3, X4) was higher than objective variables. The opposite also occur in which cross loading value of objective variables with its indicators (Y1, Y3 and Y6) was higher than trigger variables. This indicated that manifested variables value of its latent variables has better prediction. AVE values for each variable can be viewed in the table below.

TABLE 6

AVERAGE VARIANCE EXTRACTED (AVE) VALUES

\begin{tabular}{|c|c|}
\hline Variables & Average variance extracted (AVE) \\
\hline Trigger of Enlargement & 0.670 \\
\hline Objective of Enlargement & 0.688 \\
\hline
\end{tabular}

Source : SmartPLS processing result

From the table above it can be seen that AVE value for each construct was above 0.5 , it means that the construct is valid. Reliability test was using composite reliability value $(p c)>0.7$.

TABLE 7

COMPOSITE RELIABILITY VALUES

\begin{tabular}{|c|c|c|}
\hline Variables & Composite reliability & Information \\
\hline Trigger of Enlargement & 0.801 & Reliable \\
\hline Objective of Enlargement & 0.866 & Reliable \\
\hline
\end{tabular}

Source : SmartPLS processing result 
From the table above, it can be concluded that for both trigger of enlargement and objective of enlargement variables it has composite reliability value $>0.7$ thus indicators used in these variables (X3, X4, Y1, Y3 and Y6) has good reliability or able to measure its construct. Therefore, measurement model (outer model) can be written as follows:

$$
\begin{aligned}
& \mathrm{X} 3=0.897 \text { Trigger }+1.145 \\
& \mathrm{X} 4=0.732 \text { Trigger }+1.145 \\
& \mathrm{Y} 1=0.920 \text { Objective }+2.034 \\
& \mathrm{Y} 3=0.890 \text { Objective }+1.995 \\
& \mathrm{Y} 6=0.652 \text { Objective }+1.358
\end{aligned}
$$

\section{b. Evaluation of structural model (inner model)}

Testing toward structural model was done by looking at its $R$-sqaure and $Q$-square value with range $0<Q^{2}<1$, whereas closer to 1 means better model. For $R$-square and $Q$-square values, it was shown in Table 8.

TABLE 8
R-SQUARE AND Q-SQUARE VALUES
\begin{tabular}{|c|c|c|}
\hline & R Square & Q Square \\
\hline Objective of Enlargement & 0.139 & 0.139 \\
\hline
\end{tabular}

Source : SmartPLS processing result

From the table above, it can be seen that $R$-square and $Q$-square values were $>0$ which means that model was also fit with the data or able to convey the phenomenon on the field. Structural model (inner model) can be written:

$Y=\gamma X+\varsigma$

Objective of Enlargement $(\mathrm{Y} 1, \mathrm{Y} 3, \mathrm{Y} 6)=0.372$ Trigger of Enlargement $(\mathrm{X} 3, \mathrm{X} 4)+1$

\subsubsection{Hypothesis Testing}

Hypothesis testing in PLS was done by resampling bootstrapping method using T-statistic. The hypothesis was "there is triggering effect of enlargement toward objective of enlargement in Amanatun".

$\mathrm{H} 0:=0$ (there is no relationship/effect)

Ha $: \neq 0$ (there is relationship/effect)

Result of T-test in PLS can be seen from table below:

TABLE 9

MEAN, STDEV,T-VALUES, P-VALUES

\begin{tabular}{|c|c|c|c|c|c|}
\hline & $\begin{array}{c}\text { Original Sample } \\
(\mathbf{O})\end{array}$ & $\begin{array}{c}\text { Sample mean } \\
(\mathbf{M})\end{array}$ & $\begin{array}{c}\text { Standard } \\
\text { Deviation (stdev) }\end{array}$ & $\begin{array}{c}\text { T Statistics } \\
(\mathbf{O} / \text { STDEV) }\end{array}$ & P Value \\
\hline Pemicu>tujuan & 0,372 & 0,396 & 0,184 & 2,027 & 0,043 \\
\hline
\end{tabular}

Source : SmartPLS processing result

From the table above it can be seen that $T$-statistic for trigger > objective of enlargement is 2,027. A hypothesis was said to have significant effect/relationship $\mathrm{x}$ toward y if T-statistic $\geq 1,96$ while $P$ value is 0,043 which means lower $(<)$ than alpha $(0,05)$ and thus null hypothesis was rejected $(\mathrm{Ha}: \neq 0)$. Thus conclusion of this hypothesis testing is there was effect/relationship between trigger of enlargement and objective of enlargement for Amanatun region.

\subsection{Analysis of Appropriateness Level based on PP of 2007}

In analyzing appropriateness level for Amanatun enlargement using PP 78 of 2007, comparison was conducted between enlargements analyses of Amanatun with other Regency existed in the Province of East Nusa Tenggara.

Based on the appendix of Government Regulation (PP) No 78 of 2007, there were 11 factors and indicators with score range from 1-5,

- Score 5 was in a category of very capable with indicators value requirement $\geq 80 \%$ of average value.

- Score 4 was in category of capable with indicators value requirement $\geq 60 \%$ of average value.

- Score 3 was in category of less capable with indicators value requirement $\geq 40 \%$ of average value. 
- Score 2 was in category of incapable with indicators value requirement $\geq 20 \%$ of average value.

- Score 1 was in category very incapable with indicators value requirement $<20 \%$ of average value.

\section{TABLE 10}

ANALYSIS AND SCORING OF INDICATORS FOR AMANATUN ENLARGEMENT BASED ON PP 78 OF 2007

\begin{tabular}{|c|c|c|c|c|c|c|}
\hline \multirow[b]{2}{*}{$\begin{array}{l}\mathbf{N} \\
\mathbf{0}\end{array}$} & \multirow[b]{2}{*}{ Factors and Indikators } & \multicolumn{2}{|c|}{ Score } & \multirow[b]{2}{*}{$\begin{array}{c}\text { Bob } \\
\text { ot }\end{array}$} & \multicolumn{2}{|c|}{ Number } \\
\hline & & $\begin{array}{l}\text { Kab.Induk } \\
\text { TTS }\end{array}$ & $\begin{array}{c}\text { Amanatun } \\
\text { Enlargement }\end{array}$ & & $\begin{array}{l}\text { Kab.Induk } \\
\text { TTS }\end{array}$ & $\begin{array}{c}\text { Amanatun } \\
\text { Enlargement }\end{array}$ \\
\hline \multirow[t]{3}{*}{1.} & Demography & & & & & \\
\hline & 1. Number of people & 5 & 5 & 15 & 75 & 75 \\
\hline & 2. Population density & 5 & 5 & 5 & 25 & 25 \\
\hline \multicolumn{5}{|c|}{ Total Demography score } & 100 & 100 \\
\hline \multirow[t]{4}{*}{2.} & Economy Capability & & & & & \\
\hline & $\begin{array}{l}\text { 1. Domestic product input for regional gross non } \\
\text { oil and gas per capita }\end{array}$ & 5 & 4 & 5 & 25 & 20 \\
\hline & 2. Economy growth & 5 & 5 & 5 & 25 & 25 \\
\hline & $\begin{array}{l}\text { 3. domestic product input for regional gross non oil } \\
\text { and gas }\end{array}$ & 5 & 3 & 5 & 25 & 15 \\
\hline \multicolumn{5}{|c|}{ Total economy capability score } & 75 & 60 \\
\hline \multirow[t]{15}{*}{3.} & Regional Potential & & & & & \\
\hline & 1. Bank ratio & 5 & 2 & 2 & 10 & 4 \\
\hline & 2. shopping group ratio / 10.000 citizen & 5 & 5 & 1 & 5 & 5 \\
\hline & 3. Market ratio / 10.000 citizen & 5 & 4 & 1 & 5 & 4 \\
\hline & $\begin{array}{l}\text { 4. Elementary school ratio / citizen eligible for } \\
\text { primary school }\end{array}$ & 5 & 5 & 1 & 5 & 5 \\
\hline & $\begin{array}{l}\text { 5. Middle school ratio / citizen eligible for } \\
\text { secondary school }\end{array}$ & 5 & 5 & 1 & 5 & 5 \\
\hline & $\begin{array}{l}\text { 6. High school ratio / citizen eligible for tertiary } \\
\text { school }\end{array}$ & 5 & 5 & 1 & 5 & 5 \\
\hline & 7. Rasio Fas.Kesehatan per 10.000 citizen & 5 & 5 & 1 & 5 & 5 \\
\hline & 8. Medical personnel ratio & 5 & 4 & 1 & 5 & 4 \\
\hline & 9. Motor vehicles & 5 & 4 & 1 & 5 & 4 \\
\hline & 10. Electricity subscribers & 5 & 4 & 1 & 5 & 4 \\
\hline & 11. Road length / number of vehicles & 5 & 5 & 1 & 5 & 5 \\
\hline & 12. High school diploma worker & 5 & 4 & 1 & 5 & 4 \\
\hline & 13. Bachelor degree worker & 5 & 3 & 1 & 5 & 3 \\
\hline & 14. Civil servant ratio & 5 & 5 & 1 & 5 & 5 \\
\hline \multicolumn{5}{|c|}{ Total Regional Potential Score } & 75 & 62 \\
\hline \multirow[t]{4}{*}{4.} & Financial Capability & & & & & \\
\hline & 1. Local income own & 5 & 2 & 5 & 25 & 10 \\
\hline & 2. Own revenue to number of citizen ratio & 5 & 5 & 5 & 25 & 25 \\
\hline & $\begin{array}{l}\text { 3. Own revenue ratio compare to gross regional } \\
\text { domestic product }\end{array}$ & 5 & 5 & 5 & 25 & 25 \\
\hline \multicolumn{5}{|c|}{ Total Financial Capability Score } & 75 & 60 \\
\hline \multirow[t]{4}{*}{5.} & Social Cultural & & & & & \\
\hline & 1. Praying facility ratio & 5 & 5 & 2 & 10 & 10 \\
\hline & 2. Sport square facility ratio & 4 & 4 & 2 & 8 & 8 \\
\hline & 3. Number of city hall & 3 & 2 & 1 & 3 & 2 \\
\hline \multicolumn{5}{|c|}{ Total Social Cultural Score } & 21 & 20 \\
\hline \multirow[t]{3}{*}{6.} & Social Political & & & & & \\
\hline & 1. Election percentage & 5 & 5 & 3 & 15 & 15 \\
\hline & 2. Number of mass organization & 3 & 2 & 2 & 6 & 4 \\
\hline \multicolumn{5}{|c|}{ Total Social Political Score } & 21 & 19 \\
\hline \multirow[t]{3}{*}{7.} & Vastness of region & & & & & \\
\hline & 1. Overall teritorial area & 5 & 1 & 2 & 10 & 2 \\
\hline & 2. Effective teritorial area & 5 & 2 & 3 & 15 & 6 \\
\hline \multicolumn{5}{|c|}{ Total Regional Vastness Score } & 25 & 8 \\
\hline \multirow[t]{3}{*}{8.} & Defence & & & & & \\
\hline & 1. Defence personnel ratio & 5 & 2 & 3 & 15 & 6 \\
\hline & 2. Teritorial characteristic & 1 & 4 & 2 & 2 & 8 \\
\hline
\end{tabular}




\begin{tabular}{|c|c|c|c|c|c|c|}
\hline \multirow{2}{*}{$\begin{array}{l}\mathbf{N} \\
\mathbf{o}\end{array}$} & \multirow[b]{2}{*}{ Factors and Indikators } & \multicolumn{2}{|c|}{ Score } & \multirow[b]{2}{*}{$\begin{array}{c}\text { Bob } \\
\text { ot }\end{array}$} & \multicolumn{2}{|c|}{ Number } \\
\hline & & $\begin{array}{c}\text { Kab.Induk } \\
\text { TTS }\end{array}$ & $\begin{array}{c}\text { Amanatun } \\
\text { Enlargement }\end{array}$ & & $\begin{array}{c}\text { Kab.Induk } \\
\text { TTS }\end{array}$ & $\begin{array}{c}\text { Amanatun } \\
\text { Enlargement }\end{array}$ \\
\hline \multicolumn{5}{|c|}{ Total Defence Score } & 17 & 14 \\
\hline \multirow[t]{2}{*}{9.} & Security & & & & & \\
\hline & 1. Security personnel ratio & 5 & 2 & 5 & 25 & 10 \\
\hline \multicolumn{5}{|c|}{ Total Security Score } & 25 & 10 \\
\hline \multicolumn{7}{|c|}{\begin{tabular}{l|l}
1 & People welfare level \\
\cline { 2 - 2 }
\end{tabular}} \\
\hline U. & 1. Human development index & 5 & 5 & 5 & 25 & 25 \\
\hline \multicolumn{5}{|c|}{ Total Welfare Score } & 25 & 25 \\
\hline \multirow{3}{*}{$\begin{array}{l}1 \\
1 .\end{array}$} & Control Range & & & & & \\
\hline & 1. Average distance & 5 & 5 & 2 & 10 & 10 \\
\hline & 2. Average time & 5 & 5 & 3 & 15 & 15 \\
\hline \multicolumn{5}{|c|}{ Total Control Range Score } & 25 & 25 \\
\hline \multicolumn{5}{|c|}{ Total Overall Score } & 484 & 403 \\
\hline
\end{tabular}

\section{Source : Analysis result}

Score for Amanatun enlargement regarding population factor was 100, score for economic capability factor was 60, score for regional potential factor was 62 and score for financial capability factor was 60. It means that it was eligible to conduct regional autonomy. Furthermore, total score for Main area in South Central Timor Regency is 484 and total score for Amanatun enlargement is 403 , it means that appropriateness category for this enlargement is capable and recommended to be pursued.

\section{CONCLUSION}

From the analysis result, conclusion can be made:

1. Trigger of Amanatun enlargement is economic imbalances and vastness of regional area.

2. Objective of Amanatun enlargement is to improve service for citizen, accelerating regional economy development and to improve safety and order.

3. Hypothesis testing result indicate that there is $37,2 \%$ relation between trigger of enlargement toward objective of enlargement in Amanatun.

4. Based on PP 78 of 2007, enlargement of Amanatun was capable and recommended to be pursued.

\section{SUGGeSTIONS}

1. For central government, there was no complementary regulation for UU 23 of 2014 particularly regarding regional enlargement and thus implementation for Amanatun enlargement was still unclear.

2. For regional government, review regarding Amanatun enlargement as capital candidate was not yet geographically reviewed particularly for disaster prone areas and one based on hydrography.

3. For subsequent study, this study has give considerable input for Amanatun enlargement plan and also various aspects regarding not yet reviewed UU 23 of 2014.

\section{REFERENCES}

[1] Adisasmita,Rahadjo. 2012. Analisis Tata Ruang Pembangunan. Yogyakarta : Graha Ilmu

[2] Alfirdaus,K \& Bayo,L. 2007. Penataan Daerah Sebagai Penataan Institusi (Territorial Reform as Institutional Building and Reform). Seminar Internasional PERCIK ke-8

[3] Arianti,N,N \& Cahyadinata,I. 2013. Kajian Dampak Pemekaran Wilayah Terhadap Kinerja dan Pemeratan Ekonomi Daerah Pesisir di Provinsi Bengkulu. Laporan Kegiatan Penelitian. Fakultas Pertanian Universitas Bengkulu.

[4] Badan Perencanaan Pembangunan Nasional bekerja sama dengan United Nation Development Program. 2007, Studi Evaluasi Pemekaran Daerah.

[5] Dirjen Otonomi Daerah, Kemendagri.2011, Laporan hasil Evaluasi Daerah Otonom Hasil Pemekaran (EDOHP).

[6] Gede,N. S, Made.2008. Pemodelan Persamaan Struktural Dengan Partial Least Square., Seminar Nasional Matematika dan Pendidikan Matematika.

[7] Ghozali,Iman.2014. Structrural Equation Modeling:Metode Alternatif dengan Partial Least Square., Semarang: Badan Penerbit Universitas Diponegoro. 
[8] Ilyas,H,Dr. Implikasi Pengalihan Sistem Pemerintahan Sentralistik ke Sistem Otonomi Daerah Terhadap NKRI Paska Perubahan UUD 1945

[9] Khairullah dan Chayadin,M. 2006. Evaluasi Pemekaran Wilayah di Indonesia : Studi Kasus Kabupaten Lahat. Jurnal Ekonomi Pembangunan Vol 11

[10] Noor,M. 2012. Memahami Desentralisasi Indonesia. Yogyakarta : Interpena

[11] O'Leary, Brendan. 2006, Analyzing Partition: Definition, Classification and Explanation (Working Paper): Mapping Frontiers, Plotting Pathways Working Paper No.27.

[12] Partnership For Governance Reform in Indonesia. 2011. Desain Besar Penataan Daerah di Indonesia. Partnership Policy Paper No $1 / 2011$

[13] Puspitasari,R. 2014. Faktor-faktor yang Mempengaruhi Pembentukan Daerah Baru (Studi Kelayakan Secara Administratif Kabupaten Indragiri Selatan). Jom FISIP Vol 1 no 2 - Oktober 2014

[14] Samosir,P,A. 2013. Pemekaran Daerah : Kebutuhan atau Euforia Demokrasi ? Mengurangi Regulasi Pemekaran.

[15] Sjafrizal.2008.Ekonomi Regional Teori dan Aplikasi. Padang : Badouse Media.

[16] Sugiyono. 2012. Statistika Untuk Penelitian. Bandung : Alfabeta

[17] Tenrini,H,R. 2013. Pemekaran Daerah : Kebutuhan atau Euforia Demokrasi ? Mengapa Harus Mekar?.

[18] Ulum, Miftahul. Tirta,Made. Anggraeni, Dian. 2014, Analisis Structural Equation Modeling (SEM) untuk Sampel Kecil dengan Pendekatan Partial Least Square (PLS),Prosiding Seminar Nasional Matematika: Universitas Jember.

[19] Yamin, S. dan Kurniawan,H.,2009, Structural Equation Modeling: Belajar Lebih Mudah Teknik Analisi Data Kuisioner dengan LISREL-PLS, Buku Seri Kedua, Jakarta:Salemba Infotek. 